UDC 546.92:546.171.1:546.264

\title{
SYNTHESIS AND PHYSICO-CHEMICAL STUDY OF PLATINUM NANOCOMPOSITE ON MESOPOROUS CARBON NITRIDE
}

\author{
V.M.Akhmedov, N.E.Melnikova, A.Z.Babayeva, G.G.Nurullayev, Z.M.Aliyeva, \\ D.B.Tagiyev
}

M.Nagiyev Institute of Catalysis and Inorganic Chemistry, NAS of Azerbaijan

advesv@gmail.com

Received 15.05.2019

\begin{abstract}
New platinum nanocomposites were synthesized using mesoporous carbon nitride as a stabilizing matrix and carrier for nanoparticles by the method of reduction of $\mathrm{H}_{2} \mathrm{PtCl}_{6} \cdot 6 \mathrm{H}_{2} \mathrm{O}$ by methanol-water mixture. The textural, morphological, optical properties, structural and phase compositions of composites with different contents of loaded platinum particles were studied. The obtained composites have prospects for use as effective heterogeneous catalysts in chemical and photo,- electrochemical processes.
\end{abstract}

Keywords: mesoporous carbon nitride, nanocomposite, platinum, physicochemical methods of analysis, heterogeneous catalysis.

https://doi.org/10.32737/0005-2531-2019-3-6-14

\section{Introduction}

In recent years, the prospects developing of heterogeneous catalysis is often associated with graphite-like carbon nitride $\mathrm{g}-\mathrm{C}_{3} \mathrm{H}_{4}-\mathrm{a}$ layered material of a conjugate structure with $s p^{2}-$ bonds between $\mathrm{C}$ and $\mathrm{N}$ atoms. Numerous nitrogen-containing functional groups $(-\mathrm{NH}-,=$ $\left.\mathrm{N}-,-\mathrm{NH}_{2},-\mathrm{N}-\mathrm{C}=\right)$ give it a pronounced basic character [1-4]. The material has an electronic structure of bonds similar to a typical semiconductor, with a band gap of moderate width -2.7 $\mathrm{eV}$, which is characterized by good lightcollecting ability and remains stable under irradiation even in the aggressive environments. The planar 2D conjugated structure provides higher charge mobility compared to OD spherical nanoparticles of conventional semiconductors [5]. Polymeric carbon nitride also has an extremely high thermal (up to $600^{\circ} \mathrm{C}$ in air) and chemical stability (in acids, bases, organic solvents). All these properties open up good prospects for creating a new class of efficient heterogeneous catalysts for the chemical and photoelectrochemical processes [6].

Conventional methods of carbon nitride synthesis by thermolysis of nitrogen-rich, inexpensive precursors (cyanamide, dicyandiamide, urea, melamine, etc.) form a non-porous graphite-like material of bulk morphology $\left(\mathrm{g}-\mathrm{C}_{3} \mathrm{~N}_{4}\right)$ [1]. $\mathrm{g}-\mathrm{C}_{3} \mathrm{~N}_{4}$ has a small specific surface area and therefore it possesses low activity in chemical catalysis. The photocatalytic efficiency of $\mathrm{g}$ $\mathrm{C}_{3} \mathrm{~N}_{4}$ is also low due to the high recombination rate of photogenerated electron-"hole" pairs and low charge transfer capacity. The small surface area limits the absorption range of the solar spectrum. Therefore, it is important to modify the texture, to modulate the electronic structure of $\mathrm{g}-\mathrm{C}_{3} \mathrm{~N}_{4}$ bulk morphology [7]. This problem is solved by creating a porous structure and elemental doping $[8,9]$.

Mesoporous carbon nitride $\left(\mathrm{mpg}-\mathrm{C}_{3} \mathrm{~N}_{4}\right)$ with pores with a diameter of $2-50 \mathrm{~nm}$ is characterized by many advantages compared with $\mathrm{g}$ $\mathrm{C}_{3} \mathrm{~N}_{4}$ bulk morphology [10]. It has a high specific surface area rich in functional groups, a large volume of uniformly sized pores, a high basicity, a controlled electronic (atomic) structure, and a low density. mpg- $\mathrm{C}_{3} \mathrm{~N}_{4}$ exhibits catalytic activity in many reactions [11].

Doping with metals is one of the effective methods for modifying the physicochemical properties of carbon nitride. The large surface area and 2D planar conjugate structure of mpg$\mathrm{C}_{3} \mathrm{~N}_{4}$ provide the possibility of fixing metals and creating nanocomposites [12-14]. Mesopores dictate the size of metal particles and contribute to their uniform distribution on the surface.

It is known that platinum is a very active catalyst for numerous chemical reactions, including those used on an industrial scale [15]. Immobilization of platinum on the mpg- $\mathrm{C}_{3} \mathrm{~N}_{4}$ surface reduces the energy of the forbidden band, 
inhibits charge carrier recombination, increases the efficiency of light absorption and, as a result, increases the photo-catalytic effect in various reactions. Platinum has a uniquely high electrocatalytic activity. Pt/mpg- $\mathrm{C}_{3} \mathrm{~N}_{4}$ having a developed pore structure will also provide fast transport of reactants to electrically active particles, and, therefore, high electrochemical activity.

Carrying out this work, we believed that using a dual approach - the simultaneous creation of mesoporosity and the hybridization of mpg- $\mathrm{C}_{3} \mathrm{~N}_{4}$ with platinum nanoparticles - can be obtained heterostructures with high catalytic activity. For the first time, new platinum composites with mpg- $\mathrm{C}_{3} \mathrm{~N}_{4}$ were synthesized by the method of chemical reduction of $\mathrm{H}_{2} \mathrm{PtCl}_{6} \cdot 6 \mathrm{H}_{2} \mathrm{O}$ with methanol-water mixture using mesoporous carbon nitride as a carrier and stabilizing matrix for nanoparticles. The textural, morphological, optical properties, structural and phase composition of composites with different content of immobilized platinum particles were studied. Platinum nanoparticles in the composite are highly dispersed, approachable and protected from agglomeration with the mpg- $\mathrm{C}_{3} \mathrm{~N}_{4}$ structure, which is crucial for potential use in catalysis.

\section{Experimental part}

Synthesis of polymer matrix mpg- $\mathrm{C}_{3} \mathrm{~N}_{4}$. The polymer matrix was synthesized by stepwise thermal condensation of the supramolecular complex of melamine and cyanuric acid, taken in weight $1: 1$ ratio, at a temperature of $550^{\circ} \mathrm{C}$ in an inert gas atmosphere [16]. Melamine (2 g) and cyanuric acid $(2.04 \mathrm{~g})$ were separately dissolved in dimethyl sulfoxide (previously melamine was subjected to ultrasonic treatment, cyanuric acid was heated to $130-140^{\circ} \mathrm{C}$ ) and then mixed on a magnetic stirrer for 10-15 min. The precipitated white sediment - melamine-cyanur complex was filtered, washed several times with ethanol, dried in an oven at $60^{\circ} \mathrm{C}$, and subjected to heat treatment at $550^{\circ} \mathrm{C}$ for 4 hours, the rate of rise of the furnace temperature was $2-3^{0} \mathrm{C} / \mathrm{min}$.

Synthesis of $\mathrm{Pt} / \mathrm{mpg}-\mathrm{C}_{3} \mathrm{~N}_{4}$ nanocomposites. Synthesis of nanocomposites was carried out by the method of "wet chemical impregnation". A typical experiment on the synthesis of nanocomposites $\mathrm{Pt} / \mathrm{mpg}-\mathrm{C}_{3} \mathrm{~N}_{4}$ with 1 wt. $\% \mathrm{Pt}$ looks as follows: $1 \mathrm{~g} \mathrm{mpg}-\mathrm{C}_{3} \mathrm{~N}_{4}$ dispersed in
$100 \mathrm{ml}$ of methanol-water $\left(90\right.$ vol. $\% \mathrm{CH}_{3} \mathrm{OH}+$ 10 vol. $\% \mathrm{H}_{2} \mathrm{O}$ ) were sonicated for $30 \mathrm{~min}$. (High Intensity Ultrasonic Liquid Processors VCX 500 SONIC). $27 \mathrm{mg} \mathrm{H}_{2} \mathrm{PtCl}_{6} \cdot 6 \mathrm{H}_{2} \mathrm{O}$ dissolved in methanols $(20 \mathrm{ml})$ was added to the resulting mpg- $\mathrm{C}_{3} \mathrm{~N}_{4}$ dispersion with continuous stirring on a magnetic stirrer at $65-70^{\circ} \mathrm{C}$ for one hour. The product, $\mathrm{Pt}(1 \%) / \mathrm{mpg}-\mathrm{C}_{3} \mathrm{~N}_{4}$, was centrifuged, washed with deionized water and dried in a vacuum oven at $40^{\circ} \mathrm{C}$. Pt $(2 \%) / m p g-\mathrm{C}_{3} \mathrm{~N}_{4}$ and $\mathrm{Pt}(3 \%) / \mathrm{mpg}-\mathrm{C}_{3} \mathrm{~N}_{4}$ were also synthesized under the same experimental conditions.

Characterization of the Pt/mpg- $\mathrm{C}_{3} \mathrm{~N}_{4}$ nanocomposites. The surface area of the samples $\left(S_{\mathrm{BET}}\right)$ was determined on a Thermo Scientific Surfer (Thermo Fisher Scientific) gas adsorption porosimeter from nitrogen adsorption data in the relative pressure range $\left(P / P_{\mathrm{o}}\right) 0.1 \div 1$ using the Brunauer-Emmett-Teller multipoint method. The total pore volume $\left(V_{\text {pore }}\right)$, the pore size distribution was determined according to desorption data according to the BarrettJoyner-Halend method.

The structural identity and phase composition of the samples were studied by powder X-ray diffraction on a D2 PHASER (Bruker) diffractometer $\left(\mathrm{Cu} K_{\alpha}\right.$-emitter, nickel filter) in the angle range $10-70^{\circ}(2 \theta)$.

The microstructure, morphology and surface relief of the samples were studied using scanning electron microscopy on a JSM-7600 F instrument (JEOL) in the LEI mode at an accelerating voltage of $15 \mathrm{kV}$ and an operating distance of $4.5 \mathrm{~mm}$ and on an Integra-Prima (HTМДТ) ${ }^{*}$ instrument in semi-contact mode in air, using silicon cantilevers with a needle radius of $20 \mathrm{~nm}$ and a resonant frequency of $1-5 \mathrm{~Hz}$, the size of the scanning area is $2 \times 2 \mu \mathrm{m}$ and $4.5 \times 4.5$ $\mu \mathrm{m}$, the scanning speed is $1.969 \mathrm{~Hz}$, the number of scanned lines in the image is 256.

Fourier IR spectra were obtained on a Varian 3600 FTIR spectrometer (Varian Inc) in the frequency range $400-4000 \mathrm{~cm}^{-1}$ in tablets with $\mathrm{KBr}$.

The diffuse reflectance spectra of the samples were taken on a SPECORD 250 PLUS (Analytic Jena) UV-Visible spectrophotometer in the wavelength range from 200 to $1000 \mathrm{~nm}$.

\footnotetext{
${ }^{*}$ in brackets the abbreviation of the Russian name
} 


\section{Results and discussion}

The method of chemical reduction of metal ions by reducing agents in the environment of steric stabilizers, implemented by deposition of metal compound on the porous matrix is one of the main methods of synthesis of composite catalysts. From the point of view of achieving high yields, the possibility of direct characterization of particles by modern methods, it has obvious advantages compared to other approaches used for this purpose [17, 18]. However, the use of ordinary mesoporous matrixes, depleted in functional groups, in the synthesis of composite materials usually results in formation of polydisperse particles both inside and on the outer surface of the composites [19].

As seen from [20], polymerization of $\mathrm{CCl}_{4}$ with ethylenediamine forms carbon mesomaterials, which, due to the high nitrogen content (molar ratio $\mathrm{C} / \mathrm{N}=5 / 1$ ), and it was shown at first that they were able to effectively stabilize the nanoparticles of noble metals. It was established that increasing the number of doping points on the surface of carbon carriers, and specifically nitrogen groups, can simultaneously reduce the size of platinum nanoparticles and their stability, preventing agglomeration.

We have suggested that mpg- $\mathrm{C}_{3} \mathrm{~N}_{4}(\mathrm{C} / \mathrm{N}=$ 0.75) rich in nitrogen-containing functional groups may be a promising candidate for the preparation of platinum nanoparticles and may exceed conventional mesoporous structures silicon and carbon - in terms of the effectiveness of stabilizing metal nanoparticles. The $-\mathrm{NH}-$, = $\mathrm{N}-,-\mathrm{NH}_{2},-\mathrm{N}-\mathrm{C}=$ groups framing the mesopores are the platform for immobilizing metal atoms and play a key role in the formation of highly dispersed nanoparticles. Functional amine groups in mpg- $\mathrm{C}_{3} \mathrm{~N}_{4}$ act as reducing agents, allowing the formation of highly dispersed nanoparticles [21]. The size of metal nanoparticles is controlled by the size of mesopores, i.e., it is possible to form highly dispersed nanoparticles without their agglomeration.

Mesoporous carbon nitride was obtained by thermal polycondensation of a precursor - a supramolecular complex of melamine with cyanuric acid, formed as a result of cooperative molecular assembly of the components of the complex, which are connected into stable aggregates by hydrogen bonds under equilibrium conditions. Such structures are formed spontaneously: when mixing the precursor solutions, a white precipitate is rapidly precipitated - melamine cyanurate, which was subjected to thermal polycondensation at $550^{\circ} \mathrm{C}$. The synthesis route is shown in scheme 1 .

The reducing agents commonly used in the synthesis of composites $\left(\mathrm{NaBH}_{4}\right.$, its mixtures with $\mathrm{NaOH}$, hydrazine etc.) are aggressive, and in many cases are deposited on the surface of the substrate [22]. In this regard, recovery using alcohol has obvious advantages due to its simplicity and the ability to easily control the process without having to remove the reducing agent from the reaction medium [23, 24].

The mechanism of $\mathrm{H}_{2} \mathrm{PtCl}_{6} \cdot 6 \mathrm{H}_{2} \mathrm{O}$ reduction in alcohols, including methanol and methanol-water mixtures, is described in detail in [25, 26]. It was shown that the route of synthesis of platinum nanoparticles strongly correlates with the presence of water. The presence in the system of additional quantities of water (up to 10 vol.\%) significantly accelerates the rate of the reaction. It should be noted that the average diameter of platinum particles in colloidal dispersions obtained by reduction with alcohols is 2.7 $\mathrm{nm}$, the particle size distribution is within $5 \mathrm{~nm}$. Nanoparticles rapidly undergo aggregation in solution with the formation of agglomerates with 100-200 platinum particles [26], therefore the presence of a stabilizer is necessary. In this study, numerous nitrogen-containing functional groups of polymeric carbon nitride are coordinated with platinum and act as ligands, ensuring effective stabilization of immobilized metal nanoparticles. The samples of composites with different amounts of platinum loaded on the mesoporous matrix $(\mathrm{MCN})$ were synthesized $-1,2$ and $3 \%$, herein after referred to as $\mathrm{Pt} / \mathrm{MCN}-1$, $\mathrm{Pt} / \mathrm{MCN}-2, \mathrm{Pt} / \mathrm{MCN}-3$, respectively. The Table 1 shows the effect of the amount of loaded platinum on the physical properties and textural characteristics of the synthesized samples. 


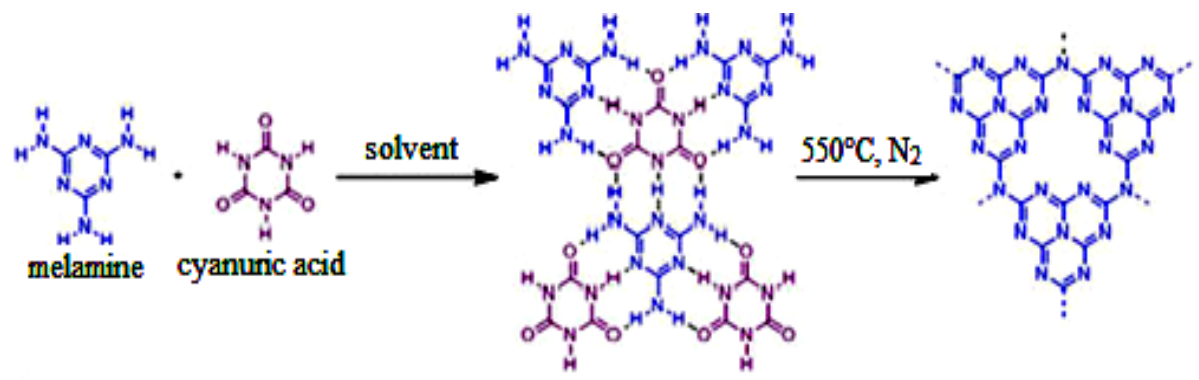

Scheme 1. Synthesis of mpg- $\mathrm{C}_{3} \mathrm{~N}_{4}$

Table 1. Physical properties and textural characteristics of the synthesized samples

\begin{tabular}{|l|c|c|c|c|c|c|c|}
\hline \multicolumn{1}{|c|}{ Sample } & $\begin{array}{c}\mathrm{Pt}, \\
\text { wt. \%/g }\end{array}$ & Color & $\begin{array}{c}S_{\mathrm{BET}} \\
\mathrm{m}^{2} / \mathrm{g}\end{array}$ & $\begin{array}{c}V_{\text {pore }}, \\
\mathrm{sm}^{3} / \mathrm{g}\end{array}$ & $\begin{array}{c}\text { Pore } \\
\text { size, } \mathrm{nm}\end{array}$ & $\begin{array}{c}\text { Band gap energy, } \\
\mathrm{eV}\end{array}$ & $\begin{array}{c}\text { Crystallinity, } \\
\%\end{array}$ \\
\hline $\mathrm{MCN}$ & - & mustard yellow & 53 & 0.58 & 30 & 2.8 & 36.8 \\
\hline $\mathrm{Pt} / \mathrm{MCN}-1$ & 1 & light marsh & 52 & 0.49 & 25 & 2.72 & 45.1 \\
\hline $\mathrm{Pt} / \mathrm{MCN}-2$ & 2 & green & 51 & 0.53 & 27 & 2.7 & 43.2 \\
\hline $\mathrm{Pt} / \mathrm{MCN}-3$ & 3 & dark green & 50 & 0.55 & 28 & 2.6 & 41.3 \\
\hline
\end{tabular}

The nitrogen adsorption-desorption isotherms of the mesoporous matrix and composites are associated with capillary condensation in mesosized pores and correspond to typical IV type isotherms according to the BrunauerEmmett-Teller classification [27], indicating the presence of mesopores $(2-50 \mathrm{~nm})$. The nanocomposite isotherm is more steep than the matrix at elevated relative pressures, which indicates that the composite has a smaller pore volume and surface area compared to the matrix because the pores are occupied by $\operatorname{Pt}(0)$. In the absence of other reagents in the reduction process, the decrease in the amount and total pore volume in the composite is apparently due to the presence of platinum particles in the pores. Thus, being in a nanoscale state, platinum, partially occupying the pore volume, leaves them unlocked. An analysis of the pore size distribu- tion curve calculated from desorption data shows that the pore size lies in the range of 18$40 \mathrm{~nm}$. The main volume of mesopores falls on pores with a diameter of $22-35 \mathrm{~nm}$.

The phase structure of the matrix and composites was analyzed on the basis of X-ray diffraction data (Figure 1), which confirmed the formation of graphite-like structures and composites based on them.

There are two peaks in all the samples of the matrix and composites: a weak diffraction peak of $13.1^{0}$, indexed in the plane (100), corresponds to the intraplane structural arrangement of three-s-triazine units with a period of $6.91 \AA$, and a strong reflex at $27.4^{0}$, indexed in the plane (002), fixing the interlayer packing of conjugated aromatic systems and the corresponding interlayer distance $d=3.26 \AA$.

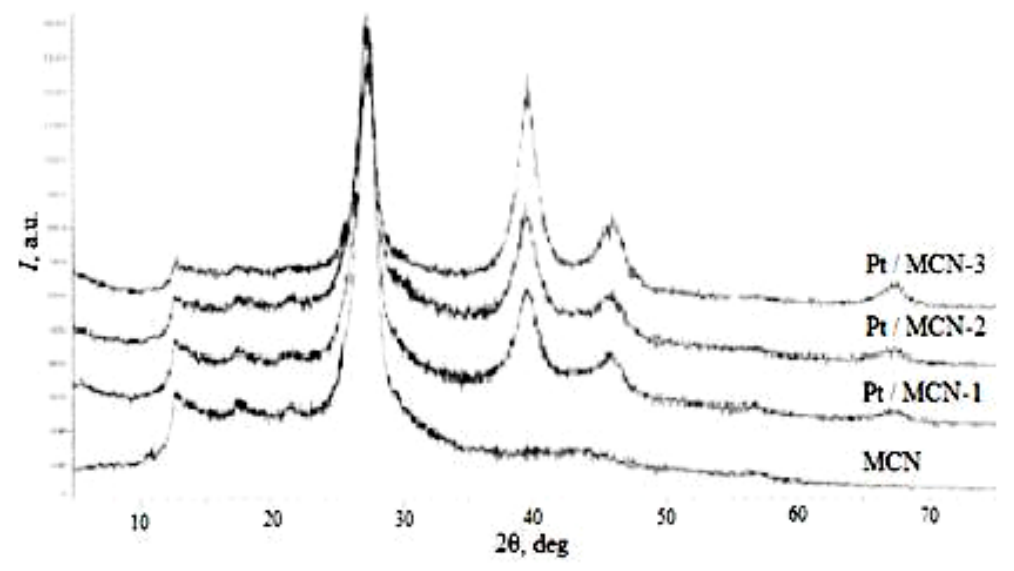

Fig. 1. X-ray diffraction of the matrix and samples of nanocomposites. 
These data are in good agreement with accepted standards for graphite structures (JCPDS card No. 87-1526) and data from the literature [28-30].

With the intercalation of metal into the MCN structure, the diffraction patterns change. On spectral lines Pt/MCN-1, Pt/MCN-2, Pt/MCN-3 additional characteristic peaks are observed - at $2 \theta 39.60^{\circ}, 46.05^{\circ}, 67.18^{0}$, which can be identified as X-ray diffraction from (111), (200), (220) platinum metal crystals (according to JCPDS card No. 65-2868). It indicates that the nanoparticles in the composite represent is a pure crystalline plate with a facecentered cubic structure [31, 32]. The intensity of the reflexes in these planes increases with the number of loaded Pt.

Three additional reflections confirm the deposition of platinum nanoparticles on the mpg- $\mathrm{C}_{3} \mathrm{~N}_{4}$ layers. The simultaneous presence of the Pt and MCN planes confirms the formation of nanocomposites. Changes in the position of the MCN peaks after the intercalation of plati-

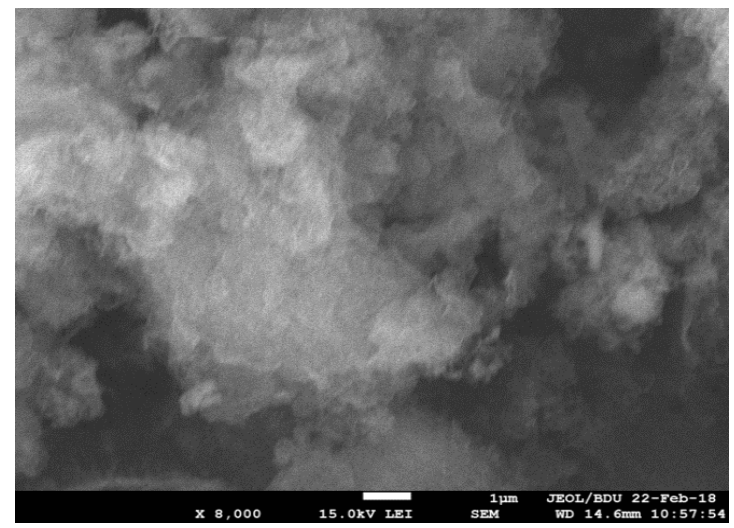

num into the polymer matrix does not occur, which indicates that platinum nanoparticles are not included in the crystal lattice of the polymer matrix, but are adsorbed on the surface of pores. According to X-ray structural analysis, the average crystallite size of platinum, calculated using the Debye-Scherrer formula [33], is 30-39 nm.

Figures 2 and 3 illustrate the SEM images of the matrix and nanocomposite (using $\mathrm{Pt} / \mathrm{MCN}-3$ as an example) surfaces, that metal nanoparticles are evenly spaced. The form of platinum nanoparticles is close to spherical, and their sizes, depending on the concentration of $\mathrm{Pt}$ (0), vary within $18-43 \mathrm{~nm}$.

For a more detailed study of the morphology and nanorelief of the surface of the matrix and composite, the atomic force microscopy method was used. Figures 4 and 5 show typical AFM 2D, 3D images of MCN and a nanocomposite (using Pt/MCN-3 as an example).

Information on the structure of the synthesized samples was obtained using FT IR spectroscopy.

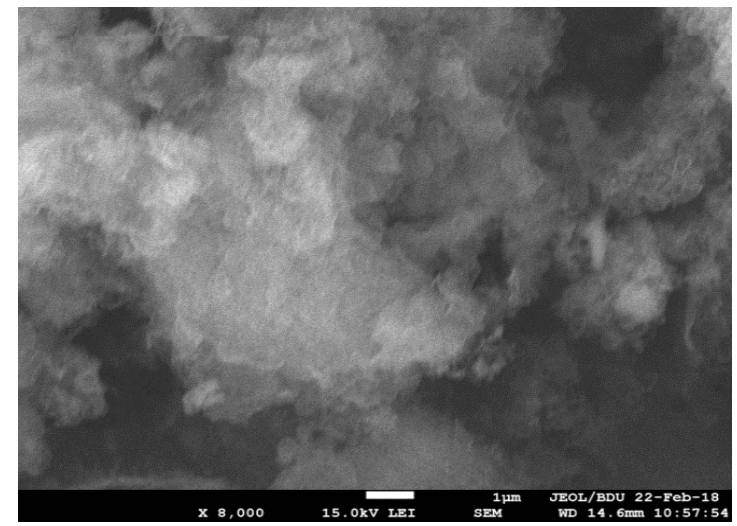

Fig. 2. SEM image MCN
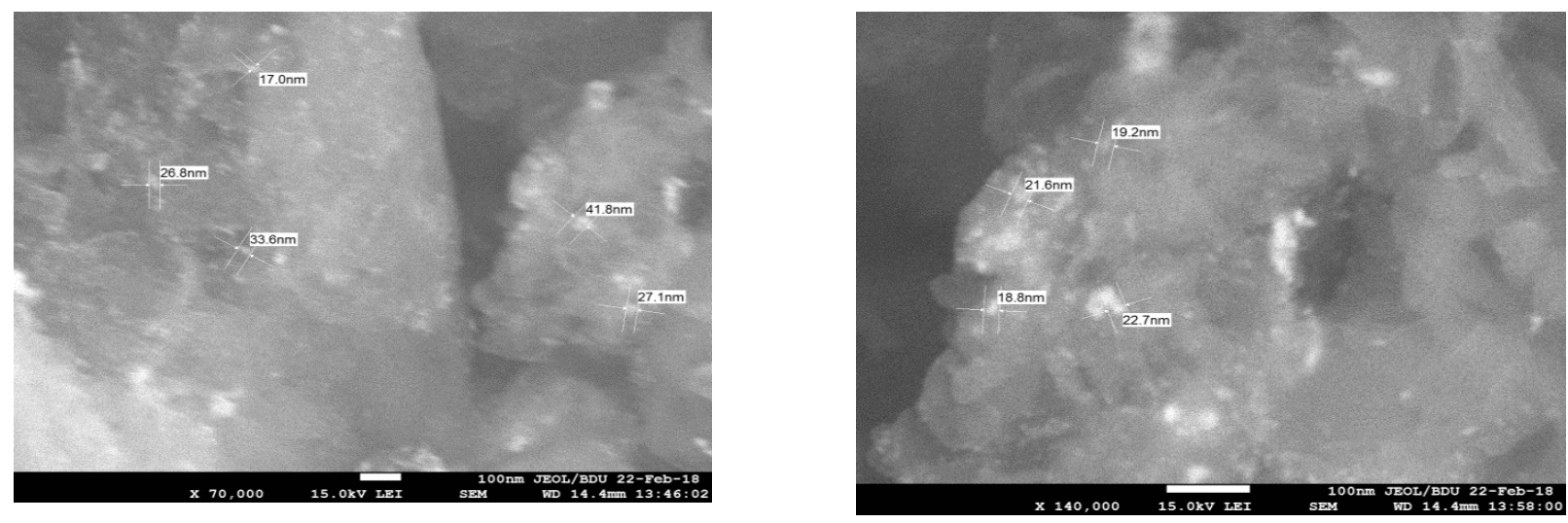

Fig. 3. SEM images of platinum particles in the $\mathrm{Pt} / \mathrm{MCN}-3$ nanocomposite composition. 

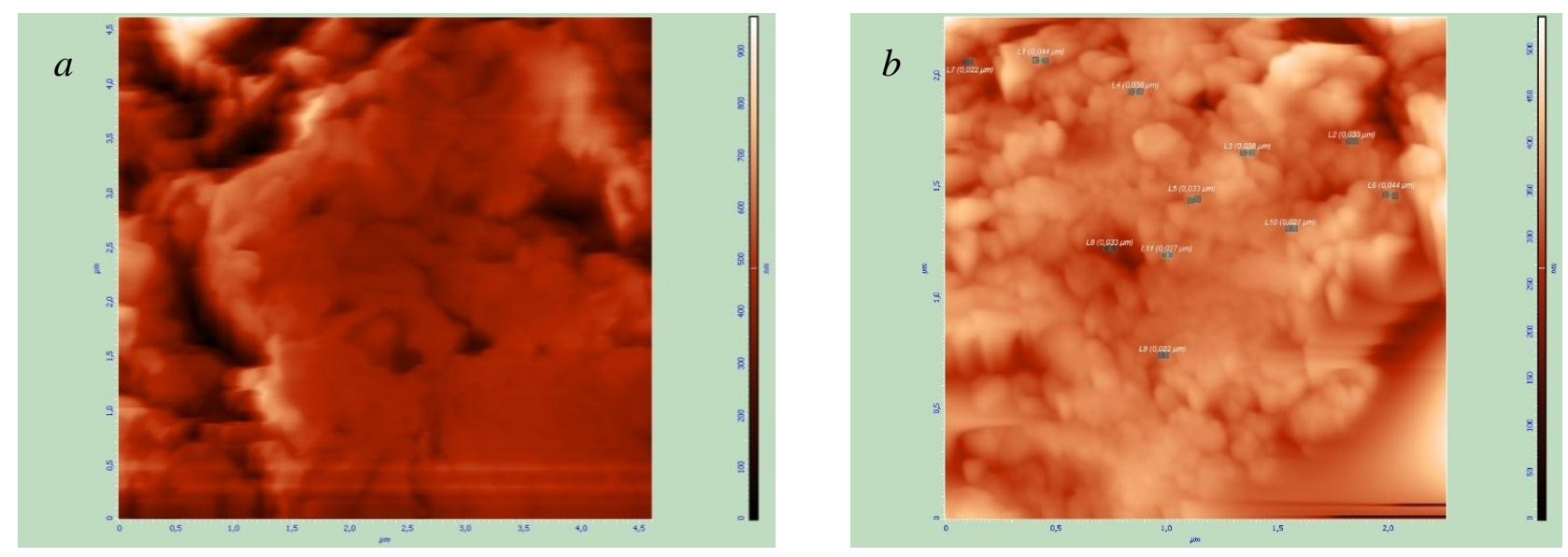

Fig. 4. Topographic AFM 2D images of MCN (a) and Pt/MCN-3 (b).
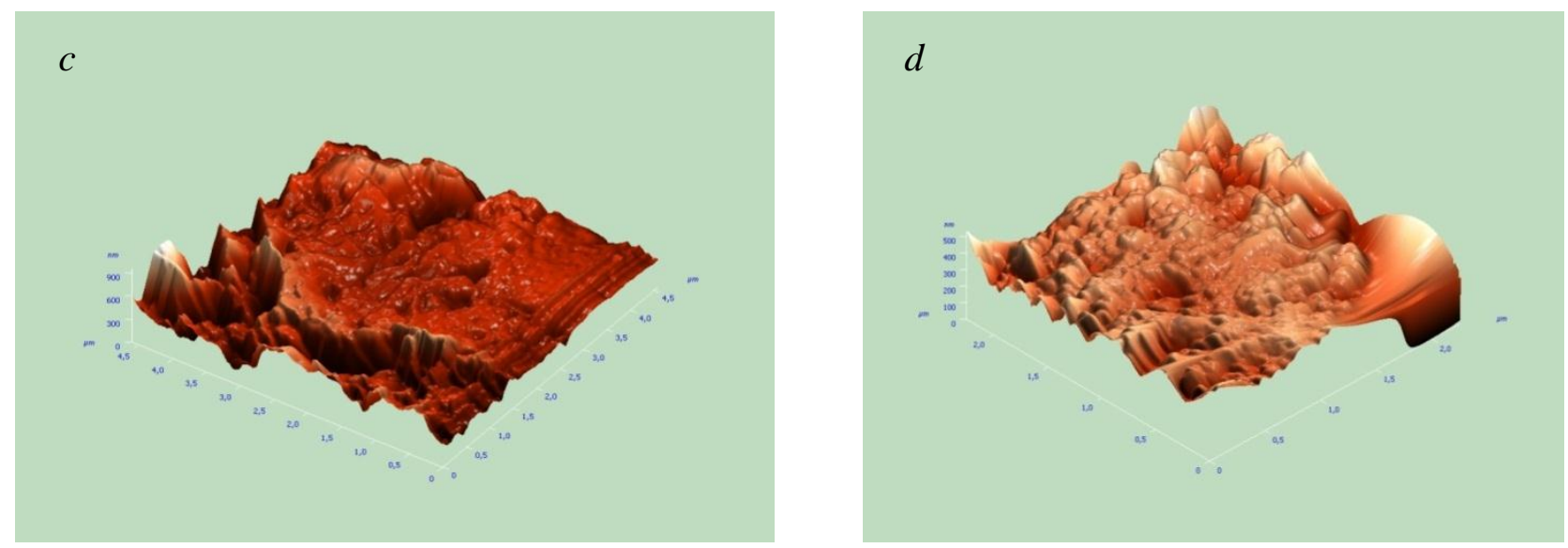

Fig. 5. Topographic AFM 3D images of $\mathrm{MCN}(c)$ and $\mathrm{Pt} / \mathrm{MCN}-3$ (d).

The spectral patterns of the polymer matrix of MCN and nanocomposites (Figure 6) are almost identical. In all spectra, bands characteristic of pure $\mathrm{g}-\mathrm{C}_{3} \mathrm{~N}_{4}$ are detected. Small differences are the result of an interaction of the elements of the matrix with the surface of the nanosized particles at the molecular level.

In all spectra in the range of 1460-1750 $\mathrm{cm}^{-1}$, there are strong bands concentrated in the matrix at $1637.110,1570.405,1541.577$ and $1458.443 \mathrm{~cm}^{-1}$, related to the stretching vibrations of conjugated $\mathrm{C}-\mathrm{N}$ bonds in the heterocycle. The position of these bands in $\mathrm{Pt} / \mathrm{CN}-1$, $\mathrm{Pt} / \mathrm{CN}-2, \mathrm{Pt} / \mathrm{CN}-3$ almost completely coincides with the position in the pure matrix. Absorption at $809.714 \mathrm{~cm}^{-1}$ in the matrix and at 810.717 , $810.529,810.316 \mathrm{~cm}^{-1}$ in composites $\mathrm{Pt} / \mathrm{CN}-1$, $\mathrm{Pt} / \mathrm{CN}-2$, Pt/CN-3, respectively, characteristic of out-of-plane bending vibrations of $\mathrm{CN}$ hetero- cycles in the triazine block [34].

Characteristic absorption bands in the range of $1230-1410 \mathrm{~cm}^{-1}$ - in the matrix at 1405.666 , 1315.632, $1235.205 \mathrm{~cm}^{-1}$ and 1405.990, 1315.870, $1236.146 \mathrm{~cm}^{-1}$ in the composite $\mathrm{Pt} / \mathrm{MCN}-1$, 1406.004, 1315.877, 1235.987 in Pt/MCN-2 and $1405.880,1315.838,1235.763 \mathrm{~cm}^{-1}$ in Pt/MCN-3 are attributed to the stretching vibrations of $\mathrm{C}-\mathrm{N}(-\mathrm{C})-\mathrm{C}$ or $\mathrm{C}-\mathrm{NH}-\mathrm{C}$ [35].

The bands in the range of $3100-3500 \mathrm{~cm}^{-1}$ relate to the $\mathrm{O}-\mathrm{H}$ stretching vibrations of the absorbed water molecules and the stretching and deformation vibrations in the $\mathrm{N}-\mathrm{H}$ groups $\left(=\mathrm{NH}\right.$ or $\left.-\mathrm{NH}_{2}\right)$. In the matrix, residual amino components are fixed at 3252.974, 3166.527 $\mathrm{cm}^{-1}$, in composites the band maxima are shifted to the long wavelength region -- up to $3254.265,3166.958 \mathrm{~cm}^{-1}$. 


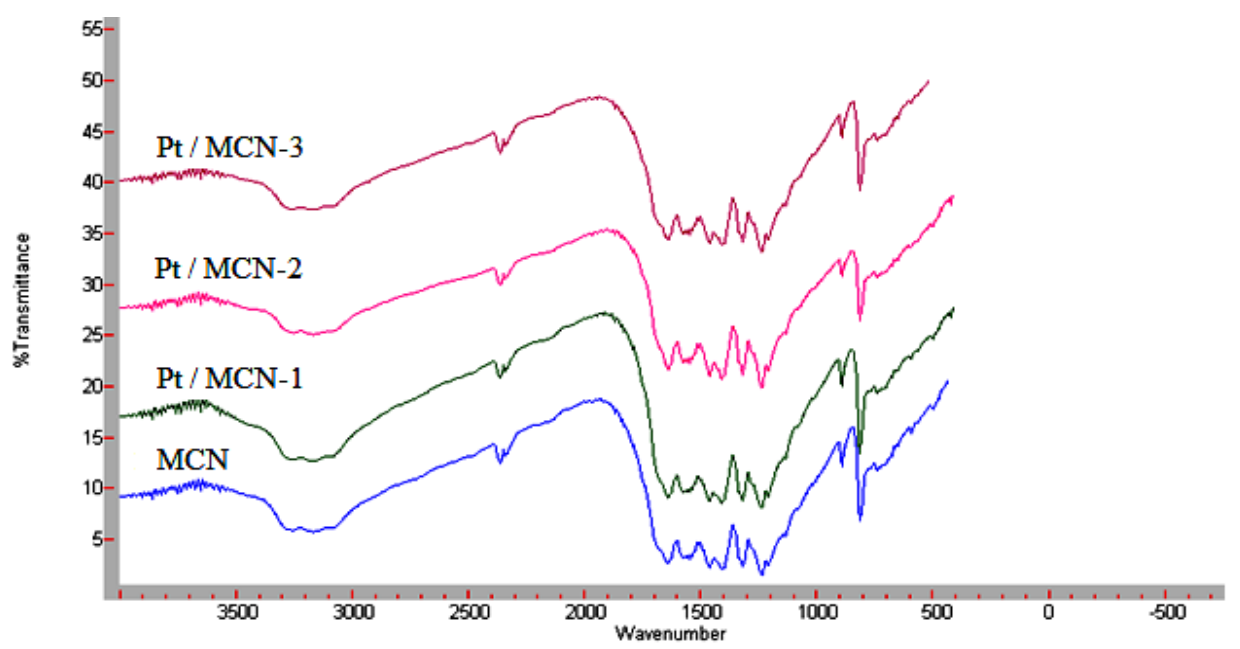

Fig. 6. FTIR spectra of MCN and nanocomposites.

Their presence and a very weak peak at $2175 \mathrm{~cm}^{-1}$, which characterizes the stretching vibrations of $\mathrm{C} \equiv \mathrm{N}$ or $\mathrm{N}=\mathrm{C}=\mathrm{N}$ groups indicates that trace amounts of precursor molecules are not completely split during pyrolysis $[36,37]$.

Analysis of the FTIR spectra allows us to conclude that the main characteristic peaks of carbon nitride are represented in all samples of the composites, which proves that the structural integrity and, consequently, specific physicochemical properties remain intact and remain unchanged.

The optical properties of MCN and nanocomposites obtained on its basis were studied by electron diffraction reflection spectroscopy in the UV - visible spectral region (Figure $7 a, b$ ).

For MCN, the absorption edge is fixed at $440 \mathrm{~nm}$. In composites, there is a "red" shift in the absorption edge by about $20-40 \mathrm{~nm}$, as the amount of loaded platinum increases. The intensity of absorption by composites in the visi- ble part of the spectrum - after $500 \mathrm{~nm}$ - increases markedly (Figure $7 a$ ). It should be noted that simultaneously with an increase in the amount of platinum in the composite, the background absorption in this area also increases, which is in good agreement with the color of the samples, which varies from yellow to almost black (Table 1). This fact is the result of direct absorption of light by dark platinum particles in the composite and a natural confirmation of its presence [38]. The band gap of the synthesized samples was calculated from the graph of Tauc (Figure $7 b$, for the $\mathrm{Pt} / \mathrm{MCN}-3$ sample). For the matrix, it is $2.8 \mathrm{eV}$, which is in good agreement with the literature data $[1,4,6]$. In composites, it decreases to 2.61 , i.e. by 0.2 $\mathrm{eV}$. Thus, the result of doping platinum on a mesoporous matrix is an increase in the absorption of visible light and a narrowing of the band gap in composites.

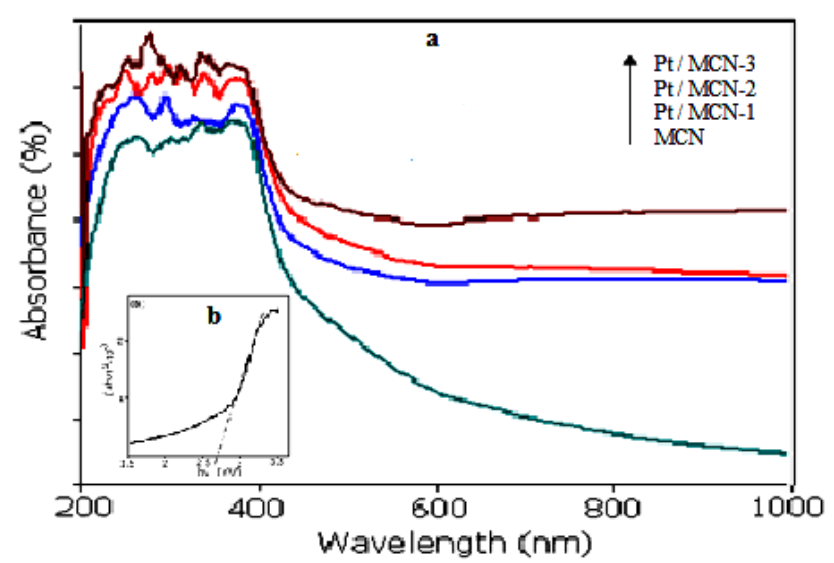

Fig. 7. Electronic diffuse reflectance spectra of MCN and nanocomposites. 


\section{Conclusions}

Developed nanocomposites based on mpg$\mathrm{C}_{3} \mathrm{~N}_{4}$ and platinum. The synthesized samples were characterized by the methods of X-ray, FTIR-, UV-Vis spectroscopy, scanning electron and atomic force microscopy, and BET- analysis. The obtained nanocomposites have an ordered texture with a fairly uniform distribution of platinum nanoparticles on the matrix, narrowed by the forbidden zone. Metal particles fixed on a mesoporous matrix are not prone to agglomeration. Composites have prospects for use in chemical, photo- and electrocatalysis.

\section{References}

1. Thomas A., Fischer A., Goettmann F.,Antonietti M., Müller J.O., Schlögl R., Carlsson J.M. Graphitic carbon nitride materials: variation of structure and morphology and their use as metal-free catalysts J. Mater. Chem. 2008. V. 18. P. 4893-4908.

2. Su D.Sh., Zhang J., Frank B., Thomas A., Wang X., Paraknowitsch J., Schlögl R. Metalfree heterogeneous catalysis for sustainable chemistry // ChemSusChem. 2010. V. 3. P. 169-180.

3. Zhu J., Xiao P., Li H., and C.Carabineiro S.A. Graphitic carbon nitride: synthesis, properties and applications in catalysis. ACS Appl. Mater. Interfaces. 2014. V. 6 . P. 16449-16465.

4. Dong G., Zhang Y., Pan Q., Qiu J. A fantastic graphitic carbon nitride $\left(\mathrm{g}-\mathrm{C}_{3} \mathrm{~N}_{4}\right)$ material: Electronic structure, photocatalytic and photoelectronic properties. J. Photochem. Photobiology C: Photochem. Reviews. 2014. V. 20. P. 33-50.

5. Ida S. and Ishihara T. Recent progress in twodimensional oxide photocatalysts for water splitting. J. Phys. Chem. Lett. 2014. V. 5. P. 2533-2542.

6. Wen J., Xie J., Chen X., Li X. A review on g$\mathrm{C}_{3} \mathrm{~N}_{4}$-based photocatalysts. Appl. Surface Sci. 2017. V. 391. P. 72-123.

7. Wang Y., Wang X., Antonietti M. Polymeric graphitic carbon nitride as a heterogeneous organocatalyst: from photochemistry to multipurpose catalysis to sustainable chemistry. Angewandte Chemie International Edition. 2012. V. 51. P. 68-89.

8. Zheng Y., Liu J., Liang J., Jaroniec M., Qiao Sh.Z. Graphitic carbon nitride materials: controllable synthesis and applications in fuel cells and photocatalysis. Energy Environ. Sci. 2012. Issue 5. P. 6717-6731.

9. Sun Sh. and Liang Sh. Recent advances in functional mesoporous graphitic carbon nitride $\left(\mathrm{mpg}-\mathrm{C}_{3} \mathrm{~N}_{4}\right)$ polymers. Nanoscale. 2017. V. 9. P. 10544-10578.

10. McCusker L.B., Liebau F., Engelhardt G. Nomenclature of structural and compositional characteristics of ordered microporous and mesoporous materials with inorganic hosts (IUPAC Recommenda- tions 2001). Pure Appl. Chem. 2001. V. 73. No 2. P. 381-384.

11. Akhmedov V.M., Melnikova N.E., Akhmedov I.D. Sintez, svoistva i primenenie poli-mernykh nitridov ugleroda. Izv. AN Ser. him. 2017. № 5. S. 782-807. Akhmedov V.M., Melnikova N.E., Akhmedov I.D. Synthesis, properties, and application of polymeric carbon nitrides Russian Chem. Bulletin. In. Edition. 2017. № 5. P. 782-807.

12. Wang L., Wang Ch., Hu X., H.Xue, Pang H. Metal/Graphitic carbon nitride composites: synthesis, structures, and applications. Chem. As. J. 2016. V. 11. P. 3305-3328.

13. Wang X., Chen X., Thomas A., Fu X. and Antonietti M. Metal-containing carbon nitride compounds: A new functional organic-metal hybrid material. Adv. Mater. 2009. V. 21. P. 1609-1612.

14. Zhao Z., Sun Y., Dong F. Graphitic carbon nitride based nanocomposites: A review Nanoscale. 2015. V. 7. P. 15-37.

15. Poling L., Poling P. Obshchaia himiia. M.: Mir, 1978. $674 \mathrm{~s}$

16. Jun J.-S., Lee E.Z., Wang X., Hong W.H., Stucky G.D., Thomas A. From melamine-cyanuric acid supramolecular aggregates to carbon nitride hollow spheres. Adv. Funct. Mater. 2013. V. 23. P. 3661-3667.

17. Van Rheenen P.R., McKelvy M.J., Glaunsinger W.S. Synthesis and characterization of small platinum particles formed by the chemical reduction of chloroplatinic acid. J. Solid State Chemi. 1987. V. 67. P. 151-169.

18. White R.J., Luque R., Budarin V.L., Clarkand J.H., Macquarrie D.J. Supported metal nanoparticles on porous materials. Methods and applications. Chem. Soc. Rev. 2009. V. 38. P. 481- 494.

19. Kosuge K., Sato T., Kikukawa N., Takemori M. Morphological control of rod and fiberlike SBA-15 type mesoporous silica using water-soluble sodium silicate Chem. Mater. 2004. V. 16. P. 899-905.

20. Vinu A., Ariga K., Mori T., Nakanishi T., Hishita S., Golberg D., Bando Y. Preparation and characterization of well-ordered hexagonal mesoporous carbon nitride Adv. Mater 2005. V. 17. P. 1648-1652.

21. Li X.H., Antonietti M. Metal nanoparticles at mesoporous N-doped carbons and carbon nitrides: functional Mott-Schottky heterojunctions for catalysis. Chem. Soc. Rev. 2013. V. 42. P. 6593-6604.

22. Yu J., Wang K., Xiao W., Cheng B. Photocatalytic reduction of $\mathrm{CO}_{2}$ into hydrocarbon solar fuels over g$\mathrm{C}_{3} \mathrm{~N}_{4}$-Pt nanocomposite photocatalysts. Phys. Chem. Chem. Phys. 2014. V. 16. P. 11492-11501.

23. Hirai H., Nakao Y., Toshima N. Preparation of colloidal transition metals in polymers by reduction with alcohols and ethers. J. Macromol. Sci.: Part AChemistry. 1979. V. 13. P. 727-750.

24. Hirai H. Formation and catalytic functionality of synthetic polymer-noble metal colloid. J. Macromol. Sci.-Chem. 1979. A 13. P.633-649. 
25. Chen Sh., Yang Q., Wang H., Zhang Sh., Li J., Wang Y., Chu W., Ye Q., Song L. Initial reaction mechanism of platinum nanoparticle in methanol water system and the anomalous catalytic effect of water. Nano Lett. 2015. V. 15. P. 5961-5968.

26. Lin C.S., Khan M.R., Lin S.D. The preparation of Pt nanoparticles by methanol and citrate J. Colloid Interface Sci. 2006. V. 299. P. 678-685.

27. Sing W. K.S., Everett D.H., Haul W.R.A., Moscou L., Pierotti R.A., Rouquerol J. and Siemieniewska T. Reporting physisorption data for gas/solid systems - with special reference to the determination of surface area and porosity. Pure Appl. Chem. 1985. V. 57. P.603-619.

28. Wang X., Maeda K., Chen X., Takanabe K., Domen K., Hou Y., Fu X. and Antonietti M. Polymer semiconductors for artificial photosynthesis: hydrogen evolution by mesoporous graphitic carbon nitride with visible light . J. Am. Chem. Soc. 2009. V. 131. P. 1680-1681.

29. Ge L. Synthesis and photocatalytic performance of novel metal-free $\mathrm{g}-\mathrm{C}_{3} \mathrm{~N}_{4}$ photocatalysts. Materials Lett. 2011. V. 65. P. 2652-2654.

30. Sun B.-w., Yu H.-y., Yang Y.-j., Li H.-j., Zhai Ch.y., Qian D.-J. and Chen M. New complete assignment of X-ray powder diffraction patterns in graphitic carbon nitride using discrete Fourier transform and direct experimental evidence. Phys. Chem. Chem. Phys. 2017. V. 19. P. 26072-26084.

31. Chen M.-L., Park Ch.-Y., Choi J.-G., Oh W.-Ch. Synthesis and characterization of metal $(\mathrm{Pt}, \quad \mathrm{Pd}$ and Fe) - graphene composites. J. Korean Ceramic Soc. 2011. V. 48. P. 147-151.

32. Ong W.-J., Tan L.-L., Chai S.-P., Yong S.-T. Heterojunction engineering of graphitic carbon nitride ( $\mathrm{g}$ $\mathrm{C}_{3} \mathrm{~N}_{4}$ ) via $\mathrm{Pt}$ loading with improved daylight-induced photocatalytic reduction of carbon dioxide to methane. Dalton Trans. 2015. V. 44. P. 1249-1257.

33. Harold P.K., Leroy E.A. X-Ray diffraction procedures: for polycrystalline and amorphous materials $\left(2^{\text {nd }}\right.$ Edition). New York: John Wiley \& Sons, 1974. 992 p.

34. Shalom M., Inal S., Fettkenhauer C., Neher D., Antonietti M. Improving carbon nitride photocatalysis by supramolecular preorganization of monomers. J. Am. Chem. Soc. 2013. V. 135. P. 7118-7121.

35. Liu J.H., Zhang T.K., Wang Z.C., Dawson G., Chen W. Simple pyrolysis of urea into graphitic carbon nitride with recyclable adsorption and photocatalytic activity. J. Mater. Chem. 2011. V.21. P. 14398-14401.

36. Zhang G.G., Zhang J.S., Zhang M.W., Wang X.C. Polycondensation of thiourea into carbon nitride semiconductors as visible light photocatalysts . J. Mater. Chem. 2012. V. 22. P. 8083-8091.

37. Bojdys M.J., Müller J.O., Antonietti M., Thomas A. Ionothermal synthesis of crystalline, condensed, graphitic carbon nitride. J. Chem. Eur. 2008. V. 14. P. 8177-8182.

38. Bai X., Zong R., Li C., Liu D., Liu Y., Zhu Y. Enhancement of visible photocatalytic activity via $\mathrm{Ag} @ \mathrm{C}_{3} \mathrm{~N}_{4}$ core-shell plasmonic composite. Appl. Catalysis B: Environmental. 2014. V. 147. P. 82-91.

\section{MEZOMӘSAMəLI KARBON NITRID OSASINDA PLATIN NANOKOMPOZITLəRININ SINTEZI Və FİZIKİ-KIMYəVI TəDQIQQi}

\section{V.M.Ohmədov, N.Y.Melnikova, A.Z.Babayeva, Q.Q.Nurullayev, Z.M.Oliyeva, D.B.Tağıyev}

Mezoməsaməli karbon nitriddən nanohissəciklərin daşıyıcısı və stabilləşdiricisi kimi istifadə etməklə $\mathrm{H}_{2} \mathrm{PtCl}_{6} \cdot 6 \mathrm{H}_{2} \mathrm{O}$ metanol - su qarışı̆̆ı ilə kimyəvi reduksiya olunaraq platinin yeni nano-kompozitləri sintez edilmişdir. Müxtəlif miqdarda platin nanohissəcikləri saxlayan kompozitlərin tekstur, morfoloj1, optiki xassələri, quruluş və faza tərkibi tədqiq edilmişdir. Sintez edilmiş kompozitlər kimyəvi, foto-, elektrokimyəvi proseslərdə effektiv heterogen katalizator kimi tədbiq perspektivinə malikdirlər.

Açar sözlor: mezoməsamali karbon nitrid, nanokompozit, platin, fiziki-kimyəvi analiz üsullarl, heterogen kataliz.

\section{СИНТЕЗ И ФИЗИКО-ХИМИЧЕСКИЕ ИССЛЕДОВАНИЯ НАНОКОМПОЗИТОВ ПЛАТИНЫ НА МЕЗОПОРИСТОМ НИТРИДЕ УГЛЕРОДА}

\section{В.М.Ахмедов, Н.Е.Мельникова, А.З.Бабаева, Г.Г.Нуруллаев, З.М.Алиева, Д.Б.Тагиев}

Синтезированы новые нанокомпозиты платины методом химического восстановления $\mathrm{H}_{2} \mathrm{PtCl}_{6} \cdot 6 \mathrm{H}_{2} \mathrm{O}$ смесью метанол - вода с использованием мезопористого нитрида углерода в качестве стабилизирующей матрицы и носителя для наночастиц. Исследованы текстурные, морфологические, оптические свойства, структурный и фазовый составы композитов с различным содержанием загруженных наночастиц платины. Синтезированные композиты рекомендованные как перспективные для применения в качестве эффективных гетерогенных катализаторов химических, фото-, электрохимических процессов.

Ключевье слова: мезопористый нитрид углерода, нанокомпозит, платина, физико-химические методы анализа, гетерогенный катализ. 